
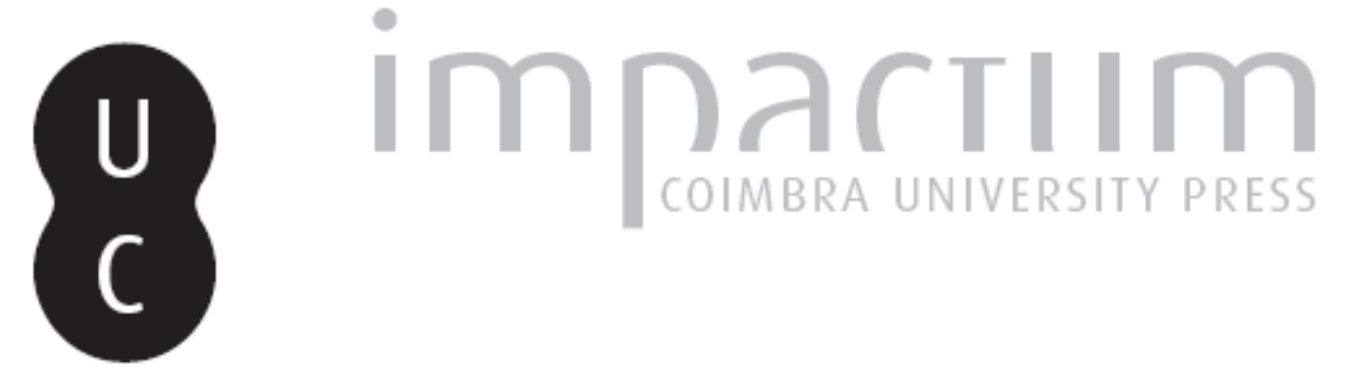

Bases y evolución de la "política portuguesa" de la Revolución Francesa entre 1789 y 1797
Autor(es):
Aymes, Jean-René

Publicado por: Imprensa da Universidade de Coimbra

URL persistente:

URI:http://hdl.handle.net/10316.2/43769

DOI:

DOI:https://doi.org/10.14195/2183-8925_10_10

Accessed : $\quad$ 26-Apr-2023 12:55:33

A navegação consulta e descarregamento dos títulos inseridos nas Bibliotecas Digitais UC Digitalis, UC Pombalina e UC Impactum, pressupõem a aceitação plena e sem reservas dos Termos e Condições de Uso destas Bibliotecas Digitais, disponíveis em https://digitalis.uc.pt/pt-pt/termos.

Conforme exposto nos referidos Termos e Condições de Uso, o descarregamento de títulos de acesso restrito requer uma licença válida de autorização devendo o utilizador aceder ao(s) documento(s) a partir de um endereço de IP da instituição detentora da supramencionada licença.

Ao utilizador é apenas permitido o descarregamento para uso pessoal, pelo que o emprego do(s) título(s) descarregado(s) para outro fim, designadamente comercial, carece de autorização do respetivo autor ou editor da obra.

Na medida em que todas as obras da UC Digitalis se encontram protegidas pelo Código do Direito de Autor e Direitos Conexos e demais legislação aplicável, toda a cópia, parcial ou total, deste documento, nos casos em que é legalmente admitida, deverá conter ou fazer-se acompanhar por este aviso.

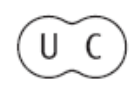


REVISTA DE HISTORIA DAS IDEIAS IO
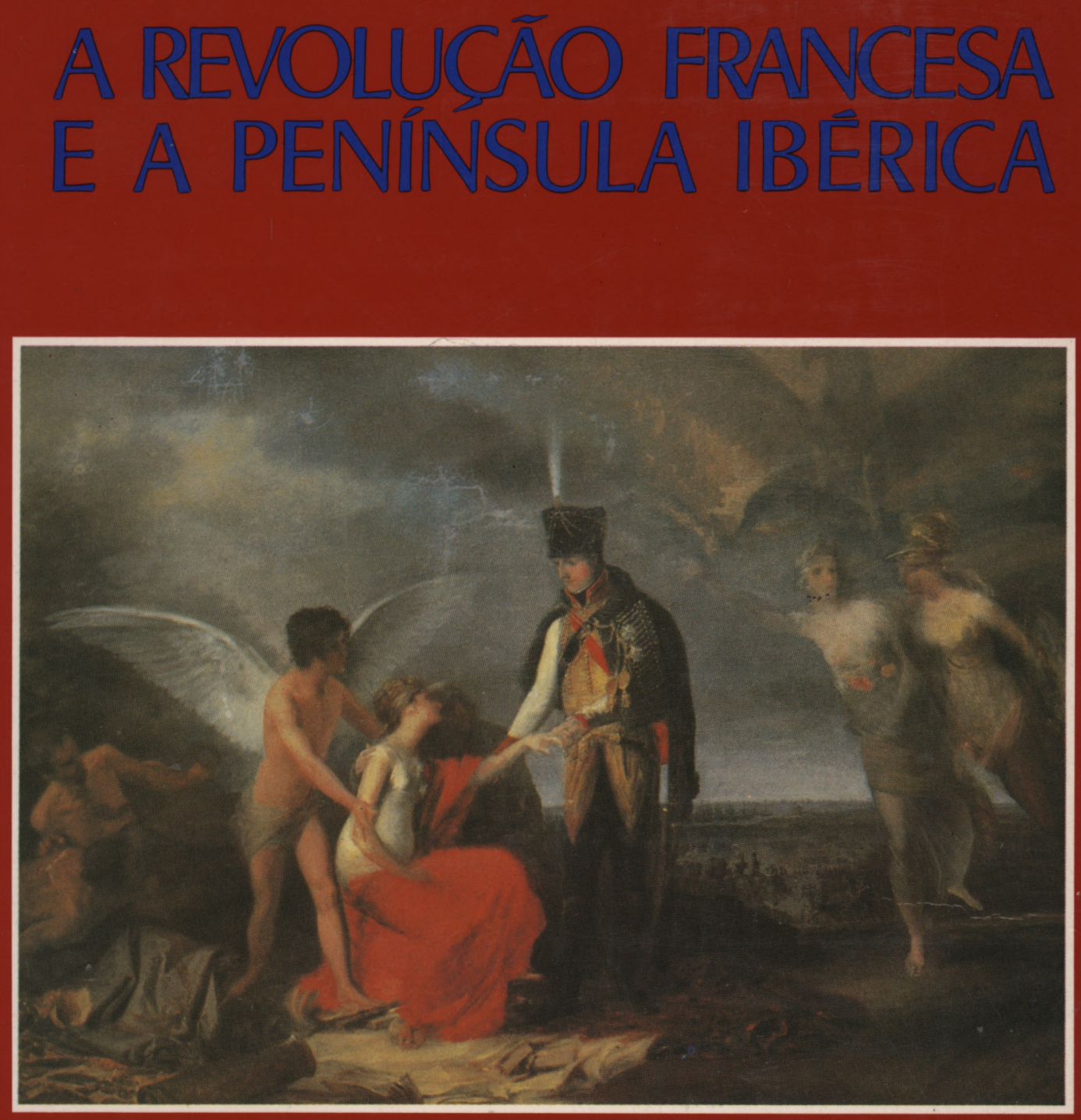

INSTITUTO DE HISTÖRIA E TEORIA DAS IDEIAS FACULDADE DE LETRAS 


\section{BASES Y EVOLUCIÓN DE LA "POLITICA PORTUGUESA» DE LA REVOLUCIÓN FRANCESA ENTRE 1789 Y 1797}

\section{Advertencias previas}

No basta con constatar la insuficiencia, cuantitativa y cualitativa, de los estudias consagrados a un tema determinado para que la elección de éste sea oportuno $\left(^{(1)}\right.$. En el caso presente, el examen de las «bases y evolución de la política portuguesa de la Revolución francesa (R.F.) entre 1789 y 1797» quizá haga de mí un cuasi-pionero, pero ello no garantiza que la exploración traiga importantes revelaciones. En efecto, me enfrento, desde el principio, con obstáculos capaces de invalidar, parcial o totalmente, mi empresa.

* Université François Rabelais - Tours.

(1) En lo que concierne a la bibliografía de idioma portugués que, naturalmente, privilegia el punto de vista portugués, los libros siguientes no son para mí de ninguna utilidad: - Joaquim Veríssimo Serrão, História de Portugal, Vol VI: O Despotismo ilustrado (1750-1807), ed. Verbo; José María Latino Coelho, Historia militar e politica de Portugal desde os fins do XVIII seculo até 1814, tomo III, Lisboa, 1891.

En lo que concierne a la bibliografía de idioma francés, me proporcionan una escasísima ayuda (este criterio es independiente de los méritos e interés intrínsecos de esos trabajos):

- Alphonse Aulard, «Etudes et leçons sur la Révolution Française" (3e série), La diplomatie du premier Comité de Salut Public, 2:" ed., Félix Alcan, Paris, 1906; Jacques Godechot, "Le Portugal et la Révolution (1789-1814)», Arquivos do Centro Cultural Português, vol. VII, Fundação Calouste Gulbenkian, Paris, 1973; Jean-François Labourdette, Le Portugal de 1780 à 1802, SEDES, Paris, 1985; Andrée Mansuy Diniz Silva, "La diplomatie portugaise et la Révolution Française» (Ponencia leída en el Coloquio "Histoire du Portugal - Histoire européenne», Paris, 22-23 de mayo de 1986 - Texto mecanografiado comunicado amablemente por la autora). 
El primer inconveniente es de orden metodológico. Para tratar con el debido rigor científico el tema escogido, se necesitaría escribir un libro, sin limitarse a una breve exposición. En él se habría de estudiar, no sólo dos distintos episodios del juego diplomático francés respecto a Portugal, sino también los antecedentes y consecuencias inmediatas del mismo. Por otra parte, conociendo de antemano la importancia que tuvieron bajo el Directorio, sobre todo en torno a Talleyrand, los «pots-de-vin», o sea el soborno, cabría escudriñar entre los bastidores de la diplomacia francesa y calibrar comparativamente el peso de los imperativos nacionales y el de las motivaciones personales de los prctagonistas y agentes subalternos de la diplomacia francesa. Por fin, importaría conocer a cada momento el punto de vista portugués, lo que exigiría la consulta sistemática de los innumerables documentos de archivos, correspondencias consulares y memorias contemporáneas, que completaran el enfoque de los sucesos ya examinados a través de las fuentes francesas. Por mi parte, he limitado mi ambición a centrarme sobre la inspección y el comentario de los archivos del ministerio parisino de Asuntos Exteriores, relativos a Portugal y repartidos entre las series "Correspondencia Política», «Correspondencia Consular» (sólo existe para Lisboa) y «Memorias y Documentos». Las piezas manuscritas que constituyen la escasa media docena de libros grandes que consulté, aunque inconexas, me proporcionaron en definitiva un material relativamente abundante que me obligó a proceder a un corte cronológico mutilador. Mientras que la fecha inicial de 1789 es incuestionable, la fecha terminal de 1797 exige una breve justificación: al final de un periodo de incertidumbre y vacilación en las relaciones franco-portuguesas, el año 1797 o «an V», según el nuevo calendario coincide por fin con la plasmación de un texto redactado minuciosamente por ser un tratado de paz, texto de cortísima vigencia, es verdad, pero que fija la situación bilateral en un momento dado. A ese argumento relacionado con el curso de la Historia se añade otro, más circunstancial y empírico: el periodo inmediatamente posterior, a partir de 1798, es mucho mejor conocido gracias al artículo de Jean Gagé, dedicado a las negociaciones secretas de Antonio de Araujo con Talleyrand $\left({ }^{2}\right)$ y gracias al libro modélico que

(2) Jean Gagé, "Antonio de Araujo, Talleyrand et les négociations secrètes pour la paix du Portugal d'après des documents inédits, conselvés aux Archives Nationales de Rio de Janeiro", Bulletin des Etudes Portugaises et de l'Institut Français au Portugal», Nouvelle Série, t. XIV, Coimbra Editora. 
André Fugier consagró a Napoleón y España $\left(^{3}\right)$ después de haber frecuentado, no sólo los archivos franceses, españoles y británicos, sino también los del ministerio portugués de Negocios Estrangeiros (Caixas da Legação en Paris) y el Arquivo Geral de Lisboa.

Pero todas estas advertencias metodológicas y precauciones oratorias no ocultan que el punto de partida de mi investigación sea un interrogante: ¿existe, sí o no, una "política portuguesa» de la R.F.? ¿Habrán definido la Convención y el Directorio, frente a Portugal, unas líneas rectoras, con la posibilidad y la voluntad de conferir a esa política cierta autonomía con respecto a la política seguida con otras naciones europeas vecinas?

Efectivamente, aparece a las claras que Portugal pocas veces es considerado aisladamente. Salvo contadas excepciones, se suele estimar que entra en un juego diplomático complejo, siempre móvil, en el que sólo se mantiene estable una escala jerárquica que es la siguiente: en la primera fila se encuentra Inglaterra, el enemigo $n .^{\circ} 1$ y ancestral de Francia, que ésta no puede invadir ni conquistar; así que, transfiriendo esa lucha en otros territorios, es en Portugal donde la R.F. procura agredir a Inglaterra y causarle sensibles prejuicios; en segunda fila se encuentra España de cuya actitud depende una intervención militar francesa en Portugal. Dado que los franceses no pueden pensar en una expedición marítima, puesto que los ingleses controlan el Océano, tienen la obligación de contar con el apoyo c. la complicidad del gobierno de Madrid para que las tropas galas atraviesen el territorio español. Los franceses hacen y harán lo posible para evitar dos alianzas - una la hispano-portuguesa, ctra la hispano-inglesa - que imposibilitarían o dificultarían la expedición a Portugal, marítima o terrestre.

Aunque aquí no me toca profundizar en este aspecto, también se puede decir que, de manera simétrica, en el otro lado, Portugal actúa diplomáticamente al lado de Inglaterra y de España, con esa diferencia esencial, con respecto a Francia, de que Portugal depende más de los dos copartícipes, mientras que Francia, más potente y ambiciosa, tiene la capacidad de tomar iniciativas, de amenazar o presionar, lo que no puede hacer Portugal. La situación incómoda y frágil de Portugal vale para el año 1789 como para el año 1798, en el que el diplomático Francisco José María de Brito explica en tono

(3) André Fugier, Nanoléon et l'Espagne, 1799-1808, 2 vol., Librairie Félix Alcan, Paris, 1930. 
amargo y desengañado por qué la negociación para la paz de Portugal siempre ha sido difícil:

"Le ha tocado a Portugal la suerte de verse ligado a dos aliados indiferentes a su bienestar, rivales en la influencia que pretenden ejercer sobre él, y finalmente enemigos declarados y recíprocamente celosos del respeto y parcialidad que los demás manifiestan hacia cada uno en particular. Como la Corte de Lisboa siempre pretendió conciliar intereses tan contrarios, era natural que se expusiera a dificultades tan escabrosas, viéndose obligado a sacrificar sus propios intereses al capricho de sus aliados» $\left.{ }^{4}\right)$.

\section{Componentes y características de la imagen de Portugal en Francia}

Antes de buscar las posibles «líneas rectoras» de la "política portuguesa» de la R.F. y de penetrar en el laberinto de las medidas puntuales, circunstanciales e inconexas que quizá constituyan por sí solas una "política portuguesa» carente de trasfondo doctrinal y de perspectivas estables, me parece útil referirme rápidamente a los relatos literarios e informes oficiales que, en total y por amalgama, configuran la imagen dominante de Portugal, vigente a los ojos de los responsables políticos de París. No pretendo que esa imagen demasiado literaria inspira una política, pero sí que, incrustándose en la mente colectiva, no deja de ejercer alguna influencia cuando los diplomáticos aconsejan una actitud más o menos hostil o cuando los responsables deciden medidas más o menos agresivas.

El librito que Daniel-Henri Pageaux consagró a las Imagens de Portugal na cultura francesa $\left({ }^{5}\right)$ nos trae algunos datos útiles, aunque necesita, en mi opinión, unos importantes complementos y matizaciones. Es verdad que, comparando con el país limítrofe, Portugal tiene mucha menor importancia a los ojos de los franceses más fascinados por el carácter medieval, africano o exótico que suelen atribuir a España. También es verdad que los viajeros galos que circulan por la península raras veces penetran en Portugal, con lo que - como lo advierte D. H. Pageaux -, o bien Portugal viene a formar como un apéndice de España, o bien ni siquiera figura al lado de España cuando la mente colectiva francesa abarca la totalidad del espacio peninsular. Pero también me interesa apuntar, para corregir ese esquema, las dos realidades siguientes: primero, si bien es

(4) Gagé, ob. cit., p. 117.

(5) Biblioteca Breve (volume 81), Instituto de Cultura e Língua Portuguesa, Ministério da Educação, Lisboa, Janeiro 1984. 


\section{La «Política Portuguesa» de la Revolución Francesa}

verdad que, desde mediados del siglo XVIII, los viajeros franceses a Portugal son muy pocos - y demasiado pocos para que el país deje de ser, como lo afirma D. H. Pageaux, una «tierra desconocida» - también es verdad que los lectores franceses que se interesen por Portugal pueden acudir a los libros, algunos de ellos traducidos al francés, que los viajeros extranjeros - sobre todo ingleses, como Twiss y Murphy $\left(^{(}\right)$- consagran a dicho país.

Aparte de esa literatura - y ya nos acercamos al mundo de la diplomacia -, los políticos franceses disponen, para su propia información, de una suma, nada despreciable, de informes confidenciales que compensan con creces la pobreza de los relatos de viajeros más propensos a describir tipos humanos y monumentos que a examinar la situación del ejército portugués - a contar los barcos surtos en el puerto de Lisboa.

Por un lado, hay cierto número de informes exclusivamente militares, conservados en el archivo del ministerio de la Guerra, en el Castillo de Vincennes, que proporcionan datos sobre las fuerzas militares (terrestres y navales), las fortalezas y los caminos, con vistas a un posible enfrentamiento armado con Portugal.

Por otro, hay una serie - más abundante de lo que se podía pensar - de informes dirigidos al ministro de Relaciones Exteriores por individuos residentes en Portugal o por agentes enviados en misión o por miembros del cuerpo diplomático. Es verdad que, comparada con la que procede de varias ciudades de España, la correspondencia de los cónsules o vice-cónsules establecidos en Portugal es muy pobre, reduciéndose a la que envía el consulado de Lisboa. Pero también hay una compensación bajo la forma de los informes, de calidad variada, que van proporcionando datos a las autoridades parisinas sobre la situación política, militar, económica, etc., de Portugal. Dicho país, al fin y al cabo, es mejor conocido en París de lo que dejaba imaginar la pobreza de la «literatura de viajes» estudiada por D. H. Pageaux. Para el periodo de la R.F. que nos interesa y para ilustrar mi afirmación, doy la lista, a continuación, de los autores de informes que contribuyeron a confirmar, completar o enmendar la imagen de Portugal que imperaba en las altas esferas de la política francesa entre 1792 y 1797: se van sucediendo los informes de Chepy (noviembre de 1792),

(6) Richard Twiss, Voyage en Portugal et en Espagne fait en 1772 et 1776, Paris, 1786; Jacques Murphy, Voyage en Portugal à travers les provinces d'Entre-Douro et Minho, de Beira, d'Estremadure et d'Alentejo dans les années 1789 et 1790...., traduit de l'anglais, de Jacques Murphy, architecte, Paris, 1797. 
Cailhasson (noviembre de 1792), Darbault (diciembre de 1793), Delauney (octubre de 1794), Lacarrière (finales de 1794), varias memorias en 1796, Le Beau (1797) y Helfflinger (1797, reedición de la memoria enviada en 1786).

\section{a) Caracterización del pueblo portugués}

El examen de estos distintos informes y de los datos dispersos en otros documentos relativos a Portugal obligan a confesar que la imagen del pueblo portugués carece de nitidez y coherencia. Es verdad que, para los políticos, la mentalidad y psicología de un pueblo extranjero - aliado o enemigo - no es un elemento determinante. En cuanto al pueblo portugués, diríase que la opinión que inspira depende de la nacionalidad del que cpina: para el inglés Murphy, es honrado, solícito, afable, bondadoso y sencillo; pero, para el francés Delauney, es ignorante, apático y sumiso; para otro francés que excepcionalmente reacciona como si fuera inglés, es sobrio y digno. En resumidas cuentas, se puede decir que el único denominador común en esas interpretaciones contrastadas es que el pueblo portugués - y ésta es una conclusión que los diplomáticos han de tomar en cuenta - es obediente y dócil, sea porque el gobierno de Lisboa no es malo en sí (versión británica, globalmente favorable a Portugal), sea porque los habitantes no han aprendido a expresar su descontento ante un gobierno malo (versión francesa). La otra característica es que esa imagen del pueblo portugués no es tan peyorativa como la del pueblo español, tachado a menudo de primitivo, bárbaro y fanático.

\section{b) La sociedad}

Considerada en sus diferentes estratos, comportamientos y mentalidades categoriales, la sociedad portuguesa no despierta mucha curiosidad intelectual en Francia. Las informaciones al respecto son escuetas e imprecisas hasta el punto de que, en este dominio, se podrían aplicar a la sociedad española. Por ejemplo, se dice que la nobleza posee fincas inmensas, sin llegar por ello a ser rica, que el bajo clero es mísero e ignorante y que, entre la gente de Iglesia, sólo los monjes disfrutan de mucho prestigio. En todos los casos, falta en esas descripciones y comentarios el «sello portugués» que sugiriera la existencia de una especificidad nacional.

También llama la atención el que los informadores se abstengan de toda esperanza excesiva en la asimilación de las 
doctrinas revolucionarias por el pueblo lusitano. El contraste con el enfoque del pueblo español es patente: hubo una época, que terminó aproximadamente cuando estalló la guerra franco-española en la primavera de 1793 , en que unos seudo-especialistas de las cosas de la península estimaban ilusionadamente que los súbditos de Carlos IV sólo esperaban la aparición de los soldados de la Revolución - sus liberadores - para acabar con el Antiguo Régimen y establecer unos lazos de fraternidad con los vecinos del norte; tal era la fe ciega en la virtud irresistible del mensaje revolucionario cada vez que lo oye un pueblo mísero y subyugado por un tirano. Pues bien, en el caso del pueblo portugués, parece como si su inercia congénita y su profunda ignorancia impidieran una toma de conciencia; ni se teme que se levante violentamente para rechazar el discurso revolucionario o la presencia de los que lo divulgan, ni se abriga la ilusión de que se irá ganando su adhesión. El único documento que contradice esa opinión general pesimista respecto a la cerrazón mental de los portugueses, lo encontré en un informe de Chaudron-Roussau, representante del Pueblo cerca del ejército de los Pirineos Orientales $\left({ }^{7}\right)$; en junio de 1794, hallándose en la capital francesa de Cerdaña, Montlouis entonces apellidada Montlibre, pretende explicar la animadversión que, en el ejército enemigo, se advierte entre españoles y portugueses; intervienen, según él, «la antipatía natural entre las dos naciones» y los malos tratamientos que los jefes españoles infligen a sus aliados; pero también estima - ien qué observaciones o informaciones se habrá fundado para llegar a esta conclusión tan inaudita? - que una porción de portugueses simpatiza con la R.F., mientras que los españoles parecen unánimes y determinados en su hostilidad. Sin que se pueda apreciar el grado de verdad que entraña la opinión del jacobino Chaudron-Roussau, interesa apuntar otra vez que la «imagen negra (negrísima) de España» no se aplica paralelamente a Portugal, y que los lusitanos suelen inspirar opiniones más matizadas que los «súbditos del tirano de Madrid». En una época - estamos en plena guerra - en que los revolucionarios franceses han renunciado a provocar una ruptura entre el pueblo español y su soberano, sorprende el que el representante del Pueblo, tal vez iluso y obcecado, crea todavía en la posibilidad de aplicar a Portugal la táctica ideal que consiste en atraer al pueblo para aislar y eliminar al monarca:

«Había entre los portugueses - asegura Chaudron-Roussau - unos hombres muy sensatos y que no carecían de ins-

(7) Actes du Comité du salut Public, t. XIV, p. 508. 


\section{Revista de Historia das Ideias}

trucción; decían que eran nuestros amigos naturales, que les habíamos ayudado, en el siglo anterior, a conquistar y conservar su independencia que les había quitado Felipe II'... Todos los hombres razonables de su país habían contemplado con alegría la Revolución francesa como un suceso que permitía establecer los antiguos lazos entre las dos naciones, porque todos habían considerado monstruoso el tratado que les unía a España y les obligaba a luchar contra nosotros.... Si, por casualidad, el Comité [de Salud Pública] quisiera negociar con la Corte de Portugal para destacarla de la coalición, acaso no le resulte inútil saber que la posición que ha tomado esa corte contra Francia dista mucho de ser aprobada por los portugueses» ( ${ }^{8}$ ).

Pero esa opinión de Chaudron-Roussau, tan prometedora de apoyo popular si la Convención emprendiera una obra de proselitismo revolucionario en Portugal, no parece encontrar eco en París donde - como lo entrevimos ya - no se toman en cuenta - y se conocen mal - las disposiciones del pueblo portugués a la hora de elaborar una política relativa a su país.

\section{c) La situación militar}

Contrastando con la abundancia de los datos acerca del comercio portugués y también con la vehemencia de las exigencias de un nuevo planteamiento de las relaciones comerciales, los datos relativos a la situación militar son escasos. En cuanto a las fuerzas terrestres, las cifras son estables y más o menos precisas, incluso si se integran las que proporcionan los ingleses Twiss (1776) y Murphy (1797). Lo mismo Delauney (1794) que Le Beau (1797) $\left(^{\circ}\right)$ estiman que los soldados ascienden a unos 30000 , cifra más bien ideal porque, según Le Beau, la deserción impide que las unidades estén completas. En marzo de 1789, el encargado de asuntos Urtubise se siente capaz de afinar su apreciación: habría 25000 soldados en tiempos de paz, 30000 en un «medio pie de guerra» (sic) y 40000 en un pie de guerra $\left({ }^{10}\right)$, lo que nos aleja mucho de los «8 000 soldados harapientos» que Joseph Baretti atribuía despreciativamente al reino de Porugal en $1760\left({ }^{11}\right)$.

(8) Ibidem.

(9) Mémoires et Documents Portugal (MDP), 1793-1823, Archives du Ministère des Affaires Etrangères (AAE), Paris. 119, AAE.

(10) Correspondance Politique Portugal (CPP), 1789-1790, vol.

(11) Joseph Baretti, Voyage de Londres a Gênes, passant par l'Angleterre, le Portugal, l'Espagne, traduit de l'anglais, Amsterdam, 1777. 


\section{La «Política Portuguesa» de la Revolución Francesa}

En cuanto a las fuerzas navales, los informes no coinciden como en el caso de las fuerzas terrestres: hay convergencia para estimar que Portugal dispone de entre 12 y 15 barcos de línea, pero el número de fragatas oscila mucho: 4 según Twiss, 12 a 15 según Delauney, 30 según Le Beau, con esta precisión de que la mentalidad de los tripulantes es malísima, porque todos anhelan servir a bordo de barcos ingleses en que estarían mejor pagados.

Globalmente, queda la impresión de que la potencia militar portuguesa es mediocre, sin más, es decir sin llegar a ser insignificante o nula.

\section{d) La situación económica y comercial}

Cualquiera que sea la rapidez de la recuperación económica de Portugal, este país se enfoca en Francia como una potencia colonial hiper-valorada. En concreto, la América portuguesa ejerce una auténtica fascinación en la que interfiere un vehemente sentimiento de codicia. Los franceses están persuadidos de que toda Europa está en una preocupante situación de dependencia respecto a Portugal para la plata, los diamantes y las maderas tropicales. De ahí un miedo constante a la carestía y a un insoportable encarecimiento de los precios.

La economía de la metrópoli portuguesa no inspira juicios tan fuertes. Con la excepción de Montanier para quien Portugal sufre todavía las consecuencias del terremoto de 1755 y de los errores del marqués de Pombal, los observadores franceses estiman que la economía ha entrado en una fase de lenta recuperación, que se podría acelerar si el imperialismo británico no se empecinara en estrangular las actividades de su aliado o, mejor dicho, de su satélite.

La dominación inglesa, con aspectos de monopolio, viene a ser el tema dominante de los informes sobre el comercio. Esa dominación aplastante se expresa a través del número de barcos ingleses que frecuentan el puerto de Lisboa. Por ejemplo, las autoridades parisinas se enteran de que, en 1788, en un total de 826 barcos, 351 son ingleses y sólo 141 franceses $\left({ }^{12}\right)$. Los informadores lamentan la pérdida del mercado portugués por los franceses; según los autores, se echa la culpa, sea al despotismo cínico del gobierno británico, sea a la debilidad o complicidad del gobierno portugués propenso a favorecer a los ingleses y a poner trabas a los franceses.

(12) CPP, vol. 119, AAE. 
Lo que no queda claro en los informes recibidos en París es si ese comercio franco-portugués, menguante en comparación con el comercio anglo-portugués, arroja o no un saldo positivo para Francia. De todas formas, los autores concluyen sobre la necesidad de un nuevo planteamiento - acudiendo a la fuerza o sólo a la persuasión - de las relaciones comerciales franco-portuguesas, tanto más cuanto que la situación parece empeorar entre 1788 y 1791: en 1788, según Urtubise, el balance sería favorable a Francia ${ }^{(13)}$; en 1791 , las opiniones se contradicen: en marzo, según el embajador portugués en París, de Sousa, el comercio franco-portugués sigue siendo beneficiario para Francia, mientras que un observador francés asegura que los barcos franceses llegan a Lisboa cargados de lastre y no de productos nacionales; a partir de 1792, ya no queda ninguna duda de que existe un desequilibrio a favor de Portugal. Conjugándose con el descenso del volumen de productos intercambiados y con la concesión por el gobierno de Lisboa de nuevas ventajas a favor de los ingleses, la situación comercial franco-portuguesa exige urgentemente importantes reformas a los ojos de las autoridades parisinas.

\section{e) La politica interior reciente y sus protagonistas}

La política interior portuguesa, probablemente porque afectó pocas veces a Francia, es muy mal conocida. El único personaje perteneciente a una época anterior a la R.F. que parece sobrevivir en la memoria colectiva francesa es el famoso (en Portugal) marqués de Pombal. Ese personaje ocupa, por ejemplo, un lugar importante en un fascículo impreso, publicado poco tiempo antes de 1789, titulado Observations sur la Décadence du Commerce du Portugal: ses causes - Moyens d'y rémédier ${ }^{14}$ ); el autor, un tal Jean Joseph Montanier, intenta demostrar que el marqués de Pombal, gran político, ha tenido una política comercial catastrófica al imponer un sistema prohibitivo que arruinó al mismo tiempo la producción industrial; la solución por la que aboga Montanier coincide con las miras de las autoridades parisinas a lo largo de la época que nos ocupa: se trata de imponer a Portugal la apertura de sus fronteras para acabar con el monopolio británico y dar entrada a los productos franceses.

(13) CPP, vol. 120, AAE.

(14) MDP, (1763-1801), AAE. 


\section{La «Política Portuguesa» de la Revolución Francesa}

Respecto a la época inmediatamente anterior a la R.F., llama la atención una reevaluación en alza de la política gubernamental portuguesa. Mientras que las observaciones de Montanier dan la impresión de que el terremoto de 1755 dejó exangüe toda la economía nacional hasta el punto de que la capital, hacia 1788, «no presenta más que miseria y pobreza», las informaciones bastante abundantes y precisas proporcionadas por el «chargé d'affaires» Urtubise a partir de 1788 señalan el abandono de la «imagen negra» tradicionalmente alimentada por un sentimiento de desprecio $\left.{ }^{15}\right)$. Los informes de Urtubise deshacen la imagen de un Portugal decadente, empobrecido y aletargado, sustituyéndola por la de un Portugal en vías de regeneración. Con esto, el reino visto desde París se hace digno de interés y capaz de excitar la codicia, mucho más que si se hubiera perpetuado la imagen arcaizante y nada atractiva de ese Montanier que afirmaba que los capitales portugueses habían desaparecido y que se había destruido la red de relaciones comerciales. Por el contrario, Urtubise recalca lo atinado y eficaz de las reformas recién emprendidas: se ha agilizado la circulación de los granos, reconstruido muchas casas en Lisboa, trazado nuevas carreteras cerca de Porto, reorganizado el ejército, creado una Academia Militar, suprimido el diezmo sobre la mano de obra... etc.

Signo aclaratorio de que, en los medios políticos franceses, Portugal queda más asociado a relaciones comerciales que a realidad política, los informes dedican poco espacio a los personajes encumbrados que ocupan el poder y orientan la diplomacia: el puerto de Lisboa cuenta más que el castillo real, y la factoría francesa más que la Corte. Exagerando apenas, yo diría que la imagen de los soberanos y de los ministros portugueses sólo se plasma a partir de 1794, año en que Delauney, buen conocedor de la realidad portuguesa, presenta un informe que sólo será superado en 1797 por los de Helfflinger $\left({ }^{16}\right)$ $\mathrm{y}$ de Le Beau.

Efectivamente, el regente João, Príncipe de Brasil, no podía impresionar mucho si - como se pretende - es inepto, estúpido, falto de experiencia, débil, dominado por su mujer (hija del rey de España) y sólo aficionado a la caza.

El vizconde Ponte de Lima, presidente del Consejo, tampoco inspira sentimientos benévolos, porque reúne en su persona dos actitudes especialmente aborrecibles en esos tiempos de revolución: es religioso hasta el fanatismo y anglófilo hasta el punto de aceptar gustoso la total dominación de Inglaterra.

(15) CPP. vol. 119. AAE.

(16) MDP (1793-1823), AAE. 
Luiz Pinto, ministro de la Marina y de los Asuntos Exteriores, inspira sentimientos contradictorios: un informador, después de presentarle como un lector de Rousseau, le concede talentos y firmeza; pero Le Beau lo considera presuntuoso, nada ilustrado, lo que contrasta con su porte majestuoso y su empeño para dominar al Príncipe.

Tampoco parece fijada la imagen de Josef de Seabra, ministro del Interior: es una lástima que su debilidad de carácter le impida manifestarse con tesón, porque el patriotismo que se le atribuye podría hacerle anglófobo $\mathrm{y}$, por tanto, disponerle a avenirse con los franceses $\left({ }^{17}\right)$.

El juego diplomático soñado: los grandes objetivos de la nueva «política portuguesa» de la Revolución francesa

Antes de que nos adentremos en el laberinto del juego diplomático franco-portugués, parece posible, abarcando la totálidad de los informes, concretar la orientación dominante que se quisiera dar a la "política portuguesa» en los tres dominios más importantes que son el militar, el político y el comercial. Conste que no se trata aquí de una política efectiva, sino de una política ideal, anhelada, concebida lejos de las esferas del poder, sin la imprescindible toma en cuenta de los innumerables obstáculos para su realización.

En el dominio militar, es de notar la ausencia de todo proyecto de expedición armada, encaminada a llevar a cabo la invasión y conquista de Portugal. Es verdad que, para pensar en esa eventualidad, hay que satisfacer una condición sine qua non: el permiso, otorgado por Madrid, para que el cuerpo expedicionario francés atraviese el territorio español. También visto desde París, Lisboa ha de parecer, a los ojos de los ignorantes, tan lejano como Varsovia o Istambul. Pero perdura el tradicional contraste entre Portugal y España: la España pirenaica, cantábrica y catalana tiene esa virtud de seguir inspirando, como en los siglos pasados, planes miríficos de invasión; en cambio, y aunque se presenta en seguida un obstáculo terri-

(17) Véase la opinión posterior del general Foy (Histoire de la guerre de la Péninsule sous Napoléon, Paris, 1827): "Il faisait parade de sentiments d'indépendance; caustique dans le propos et dur dans l'action, Scabra (sic) n'était pas un ami de la liberté; mais le décousu, les petiesses et l'intrigue lui faisaient pitié et, quoiqu'il eût été cruellement persécuté pendant 15 ans par Pombal, il n'avait pas abjuré les doctrines de l'école à laquelle se rattachaient les premiers succès de sa carrière politique». 


\section{La «Política Portuguesa» de la Revolución Francesa}

ble - el dominio del Océano por los ingleses -, queda constancia de algunos planes de intervención militar en Brasil o en Madeira ( $\left.{ }^{18}\right)$. Pero se estipula que esos territorios, después de conquistados, podrían ser, sea devueltos a Portugal, sea regalados a España, como si fueran sólo una moneda de cambio o un instrumento de presión a la hora de negociar otro tratado comercial con Portugal.

En el dominio comercial precisamente, las sugerencias o exigencias son más abundantes. Todo gira en torno a la consecución de unas condiciones más ventajosas para Francia. El objetivo mínimo y el objetivo óptimo se pueden formular así: como mínimo, Francia ha de ser tratada sobre un plano de igualdad con Inglaterra; pero lo ideal sería que disfrutara del régimen de la nación más favorecida, con exclusión correlativa de Inglaterra. Los otros objetivos, señalados en otros informes, no son más que variantes o consecuencias: necesidad de reequilibrar los intercambios entre Francia y Portugal, obtención de un permiso para que los barcos franceses puedan ampararse y abastecerse en los puertos portugueses; libertad de acceso de los comerciantes franceses a las riquezas brasileñas...

Resulta fácil resumir el objetivo político: se trata de provocar la ruptura de la alianza anglo-portuguesa o, por lo menos, de obligar a Portugal a aflojar esos lazos, reduciendo los privilegios exorbitantes de que disfruta el enemigo de Francia.

La «política portuguesa» de la R.F. será la resultante, siempre móvil y frágil, de la aplicación de esos objetivos - no hablo de alguna doctrina coherente o programa estructurado y pre-establecido - a una realidad aún más móvil, porque, sin hablar de las interferencias de los gobiernos de Londres y de Madrid, es bien conocido que, a cada sacudida de política interior bajo la Convención y el Directorio, pudo corresponder un reajuste de la política exterior.

El juego diplomático efectivo: el periodo Urtubise (observar y no hacer nada)

Una de las primeras consecuencias del trastorno revolucionario en Francia fue, a los ojos de los portugueses expectantes, la sustitución anunciada del embajador, el marqués de Bombelle, por un nuevo embajador $\left({ }^{(19)}\right.$. Aunque el nombra-

(18) Por ejemplo, en la memoria de Dhermand (marzo de 1796), MDP, 1793-1823, AAE.

(19) CPP, vol. 119, AAE. 
miento intervino en marzo de 1789 , Chalon sólo se embarca en Le Havre a principios de septiembre. Durante ese periodo de ínterin el "chargé d'affaires» Urtubise recibe muy pocas instrucciones de París. Sólo se le encomienda que procure evitar conflictos y tranquilizar a la Corte de Lisboa. La "política portuguesa» a esas alturas no parece nada dinámica, innovadora y expansionista. El gobierno de París da la impresión de satisfacerse momentáneamente del statu quo; así que Urtubise circunscribe su función a observar en torno suyo. En realiảad, actúa más como un cónsul que como un diplomático, aunque tiene el cometido de enterarse sigilosamente de las negaciones político-comerciales entre Portugal e Inglaterra.

En su correspondencia no se percibe ningún eco en Lisboa de los primeros sucesos inauditos que ocurren en París. Hay que esperar el mes de septiembre de 1789 para que las autoridades parisinas se enteren de varios acontecimientos relacionados con la R.F.:

«El gobierno acaba de prohibir al gacetero de Lisboa que en adelante inserte en sus papeles los artículos que conciernan a Francia. Estas noticias han provocado aquí una fermentación general en el espíritu del pueblo hasta el punto de que, hace algún tiempo, unos individuos del populacho han amenazado al tesorero de la lotería de darle una ensalada a la francesa (así designan la sentencia) si continuara a apoderarse de los billetes de la lotería para venderlos para su cuenta. Sólo se libró de su furor huyendo por un lugar escondido" (20).

Mientras que los informes de la serie «Memorias y Documentos» del archivo del ministerio de Asuntos Exteriores referentes a esa época suelen abarcar vastos periodos de tiempo y ofrecer programas o sugerencias para el futuro, las noticias que constituyen la «Correspondencia Política - Portugal» se acercan más a la política "día al día», integrándose en lo que se podría llamar la «histoire événementielle» de Portugal. De ahí el carácter pululante $\mathrm{y}$, muchas veces, insustancial de lcs datos que proporciona el «pequeño personal» de la embajada francesa en Lisboa. Con todo, si se procede a una reagrupación temática de esos datos y comentarios, se llegará a adivinar, más allá de esta impresión molesta de excesiva dispersión, las grandes y crecientes preocupaciones que suscita la política de la Corte de Lisboa respecto a Francia a partir de 1789.

Para empezar, sólo mencionaré algunas «affaires» que, por nimias o intranscendentes, no pueden afectar sensiblemente

(20) Ibidem. 
las relaciones franco-portuguesas, aunque susciten reacciones epidérmicas de inquietud o descontento. Me refiero aquí a las tres cuestiones siguientes: la captura del barco «La Maréchale de Wailly» por una fragata portuguesa en julio de 1789 , la hostilidad del gobierno portugués para con los misioneros franceses en Goa, demasiado activos en su proselitismo, y la reinvidicación financiera del abate francés de la orden de Clairvaux, que, dejando de cobrar la contribución que se le debía, yace en una miseria indecorosa $\left.{ }^{21}\right)$. En los tres casos, ni el cónsul ni el «encargado de negocios» que dan parte a París de esos incidentes parecen ver allí una clara intención política.

Otro grupo de medidas $\left({ }^{22}\right)$ tomadas por las autoridades portuguesas entre 1789 y 1792 suscitan mucho más la cólera de ciertos miembros del consulado y de la embajada, porque afectan a ciudadanos franceses posiblemente adictos a la R.F. Siendo política la intención subyacente, las autoridades parisinas habrán de conmoverse e intervenir. Sin entrar en el laberinto de estas "affaires». me contento, como arriba, con apuntar los temas: prohibición. para los marineros franceses, de bajar a tierra llevando uniforme (republicano) y escarapela nacional, expulsión de varios franceses residentes en Lisboa, medida que se interpreta como «una persecución de los patriotas», registro de barcos franceses en busca de libros prohibidos. y sobre todo varios encarcelamientos inadmisibles, en particular del tesorero de la factoría francesa en Lisboa, del pintor Noël, de un tal Dortionny o Dorquigny, acusado de haber fundado una logia masónica en Madeira y de Dupetithouars, capitán del barco «Le Diligent», que había salido en busca del descubridor La Peyrouse.

Otro grupo de medidas - muy poco detalladas - conciernen a un tema hiper-sensible. No se conoce al autor del informe que, en el verano de 1793. denuncia la actitud de las autoridades portuguesas respecto a los emigrados franceses que van llegando; sólo se sabe que "son acogidos con afectación», que han podido acercarse a la Corte y que algunos, pagados por el gobierno, hacen de espías (23).

Como lo vimos antes, los observadores franceses que están en el terreno se muestran aún más atentos a las medidas comerciales y económicas que afectan los intereses franceses, ya en la metrópoli donde ingleses, americanos e italianos se benefician de medidas generosas, ya en Africa, concretamente en

(21) Correspondance Consulaire Lisbonne (CCL), 1792-1804, AAE.

(22) CPP, vol. 119 y 120, y CCL, AAE.

(23) CPP, vol. 121, AAE. 
Cabinda, donde unos portugueses, desembarcados en 1791, intentan excluir a los franceses de la trata de negros, ya en América donde es viva una polémica, anterior a la R.F., en torno a la fijación de la frontera entre la Guyana francesa y el territorio brasileño perteneciente a Portugal.

Entre los distintos informadores, Urtubise se distingue por su tono desenfadado y por sus comentarios nada favorables a los defensores del Antiguo Régimen, señal de que el embajador interino se ha adherido al nuevo estado de cosas. Prueba de ello, las autoridades parisinas se complacen en manifestar su satisfacción por su diligencia en recoger informaciones ${ }^{(24}$ ). La opción política de Urtubise basta probablemente para explicar que, antes de la primavera de 1790, pida otro destino: o bien sus disensiones con el nuevo embajador Chalon se han agravado hasta el punto de imposibilitar la convivencia, o bien espera aplicar su celo patriótico-revolucionario a un territorio más propicio, en Francia o en el extranjero.

\section{El embajador Chalon al servicio de la contrarrevolución}

Cuando llegue para él el momento de ajuste de cuentas, saldrá a la luz que Chalon, cuyo verdadero apellido patronímico es Hardouin, era, bajo el Antiguo Régimen, conde de Chalon y Caballero de la Orden Real y Militar de San Luis $\left({ }^{25}\right)$. Pero esos títulos no bastaban para que se le prohibiera el ejercicio de su función diplomática; el único requisito era que manifestara su adhesión a las nuevas autoridades revolucionarias. En realidad, no sólo se abtuvo de proclamarla claramente, sino que defendió con una tibieza harto sospechosa a sus compatriotas, residentes en Portugal, que tenían dificultades con las autoridades locales.

En lugar de acudir briosa y sistemáticamente a su defensa, admite - y lo participa al ministerio de Asuntos Exteriores parisino - que varios encarcelados son, unos contrabandistas, otros vagabundos y otros - y esto es aún más revelador de sus propias convicciones - franc-masones o prorrevolucionarios exaltados. Cualquiera que sea la clase de denuncia, coincide así con las autoridades portuguesas cuyas quejas y reacciones represivas se hallan indirectamente justificadas. Ejemplo de esa connivencia con el gobierno portugués y del progresivo abandono de su obligación de ponerse al lado de

(24) CPP, vol. 119.

(25) Todos los datos proceden de CPP, vol. 119 y 120, AAE. 


\section{La «Política Portuguesa» de la Revolución Francesa}

los residentes franceses que habían adoptado el nuevo estado de cosas, en lugar de solidarizarse con el pintor Noël al que se acaba de encarcelar, estima que se trata de un ser peligrosamente agitado, culpable de haber proferido discursos obscenos. De manera general, es propenso a llamar «comportamientos indiscretos» cualesquiera actitudes de declarada adhesión al proceso revolucionario francés. Tan grave como esa aprobación implícita de una medidas de represión antirrevolucionarias tomadas por las autoridades portuguesas es la comunicación, llena de complacencia, al gobierno de París de las quejas levantadas por el gobierno de Lisboa: un lector neutral de los informes de Chalon estaría convencido de que toda la culpabilidad se ha de achacar a las autoridades de París, en Angola donde los franceses apoyan la sublevación de los negros, en Guyana donde otros franceses se instalan ilegalmente en territorios colocados bajo la soberanía de Portugal.

Otros comentarios de Chalon también habrían de suscitar sospechas en París; por ejemplo, en julio de 1790, en el conflicto exclusivamente financiero que opone la iglesia de San Luis de Lisboa a unos malos pagadores, se pone con firmeza al lado de la institución clerical francesa; el mes siguiente, proclama su alegría de que se celebre el día de San Luis, como si le interesara al embajador confirmar su apego a la persona del rey; en cambio - y esto había de tranquilizar a las autoridades parisinas -, manifiesta una anglofobia pertinaz, aunque nada exaltada, pronosticando que los ingleses, que nunca pierden de vista sus intereses, se aprovecharán de una situación de crisis para conquistar posiciones en Brasil; pero también de esa opinión se puede extraer una conclusión favorable a Inglaterra: pero es meneallo o, en otros términos, más vale pactar con el potente enemigo que lanzarse arriesgadamente en una guerra contra él. Otra consecuencia, en relación esta vez con Portugal: Chalon estima que el gobierno de Lisboa no excluye la posibilidad de concluir una alianza con Inglaterra y con España, pero, en lugar de alarmar al gobierno de París, el embajador estima que esa alianza, exclusivamente defensiva, no es peligrosa para Francia. Niega que Portugal abrigue intenciones hostiles respecto al nuevo régimen francés con quien quiere mantenerse en una posición de perfecta neutralidad. Como se ve, el principal empeño de Chalon es tranquilizar al gobierno de París, componiendo una imagen de Portugal más bien simpática; también se esfuerza por disuadirle de lanzarse en una política que le fuera abiertamente hostil.

Después de la salida de Urtubise en marzo de 1790 , sustituido por Gaudin, se puede pensar que Chalon dispone de un margen de maniobra tanto más amplio cuanto que el examen 
de los archivos parisinos da la impresión de que el embajador no recibe instrucciones precisas, como si el ministerio de París hubiera adivinado desde hacía tiempo que esas instrucciones no serían acatadas o que correrían el riesgo de ser divulgadas con la intención de causar perjuicios a las nuevas autoridades parisinas. En efecto, a pesar de la habilidad cautelosa con que el embajador redactaba sus informes, no le podía pasar desapercibida al ministro de Relaciones Exteriores la actitud censurable del representante francés en Lisboa. Por eso, con la voluntad de ponerle bajo control, en la primavera de 1792 se nombró a Cailhasson como secretario de legación, y en el verano del mismo año, a Chepy como otro secretario, para sustituir a Gaudin, sucesor de Urtubise.

\section{Chepy o la encarnación de la temible Revolución}

La llegada de Cailhasson y de Chepy aclara las cosas: alegando que no traían cartas credenciales, Chalon se niega a reconocer la validez de su designación por las autoridades parisinas $\left({ }^{26}\right)$.

Otro acontecimiento, ajeno a Portugal, viene a aclarar aún más la situación, si cabe: la destitución de Luis XVI en la famosa «noche del 10 de agosto» (de 1792), al comunicar un sesgo más radical al proceso revolucionario francés, precipita la evolución en todos los aspectcs de las relaciones franco-portuguesas.

Primero, el nuevo secretario de legación, Chepy, en lugar de ser recibido como lo fue el embajador Chalon, es decir con solemnidad y ostensible estima, lo es de manera intencionadamente afrentosa: se le retiene durante cuatro días a bordo del barco en que llegaba; pero lo que más le causa una sorpresa indignada es que el embajador Chalon no despliega ninguna energía para conseguir su puesta en libertad; al final de un breve periodo de internación, Chalon la recibe con desdén, echándole en cara el no tener carta credencial; luego, sabiéndose espiado, se resigna a ser recibido a escondidas por los residentes franceses prorrevolucionarios; al fin y al cabo, a él y a su compañero Cailhasson se les hace la existencia insoportable en medio de tanta desconfianza $u$ hostilidad sorda o abierta. Sintiéndose aislados y nada protegidos por el embajador, sino todo lo contrario, acaban viendo en la vuelta a

$\left.{ }^{26}\right)$ Todos los datos proceden de CPP, vol. 120 y de CCL, $1792-$ -1804, AAE. 


\section{La «Política Portuguesa» de la Revolución Francesa}

Francia su único escape. Peor todavía para ellos, cuando termine el periodo del Terror, su fama, quizá inmerecida, de «francos jacobinos», les perjudicará.

La segunda consecuencia de la «noche del 10 de agosto» afecta muy lógicamente al mismo embajador. El 12 de agosto, se le ordena volver a París. Distinguiéndose de la mayoría de sus colegas que, inmediatamente después de enterarse de la destitución de su rey, abandonan su función, Chalon adopta una actitud aún más rebelde negándose a volver a París y quedándose en Lisboa como si siguiera beneficiando de la confianza de las nuevas autoridades. En realidad, consta que nunca envió a las mismas su juramento de sumisión. Chepy que, a partir de entonces, viene a ser el único correspondiente con París - y, por tanto, nuestro único y parcial informador -, va acumulando las pruebas del antirrevolucionarismo del embajador reacio a la sumisión: sobre la fachada de su casa, ha conservado los emblemas del Antiguo Régimen, y se atreve a participar a Chepy su adhesión a «los hombres de Coblentz».

Aunque Chepy haya cargado las tintas, sorprende que el gobierno de París haya tardado tanto en destituir oficialmente a Chalon. Es verdad que la orden anterior de volver a la capital anunciaba, sin hacerla automática, la destitución del embajador. Pero oficialmente sólo se tomó la decisión tras lectura de un informe ante la Convención, a finales del año 1792, culpando a Chalon de «incivismo tenaz y aristccratismo rebelde»; se le conminó a que entregara los papeles y la cifra de la embajada a un nuevo agregado a la legación, llamado Darbault. Con fecha del 22 de diciembre de 1792, el Consejo Ejecutivo aprobó la destitución votada por la Convención y reiteró la orden de volver a París.

Como se puede imaginar, la destitución de Luis XVI, la llegada a Lisboa de los dos emisarios de la R.F. (Chepy y Cailhasson) y la condena por el embajador Chalon de la aceleración del proceso revolucionario en Francia perturban gravemente las relaciones franco-portuguesas y contribuyen a radicalizar las posiciones ideológicas, ya cada vez más difíciles de reconciliar.

Habiendo enmudecido Chalon para no dar la impresión de llevar un doble juego al seguir manteniendo contactos epistolares con las autoridades parisinas que quieren alejarle de su puesto diplomático, el único informador acerca de Portugal viene a ser Chepy, hasta que llegue el nuevo agregado Darbault.

Naturalmente, la imagen de Portugal elaborada por el «montagnard» Chepy (la adscripción a esta tendencia no resulta evidente) no puede coincidir con la que iba componiendo el contrarrevolucionario conde de Chalon. Y esa mutación no 


\section{Revista de História das Ideias}

puede sino repercutir en la «política portuguesa» del gobierno de París, que se hará menos amistosa, indulgente y respetuosa si se le va persuadiendo de que las autoridades portuguesas experimentan un sentimiento de creciente hostilidad respecto a los sucesos de París.

Efectivamente, los informes de Chepy y de Cailhasson dan la impresión de que la situación va empeorando en todos los aspectos: Chalon ha de ser considerado como un traídor, el cónsul y el vice-cónsul como unos contrarrevolucionarios; el abate Grenier, capellán del hospital San Luis, desempeña un papel contrarrevolucionario relevante...

En el otoño de 1792 casi se ha llegado al punto de ruptura, a pesar de que, a mediados de septiembre, el Consejo Ejecutivo ha mandado a Chalon que, en el momento de despedirse de las autoridades portuguesas, manifestara a éstas el deseo francés de mantener con Portugal la amistad más perfecta y duradera. Pero Chepy, por su lado, considera la situación con un pesimismo airado: en octubre, es decir tardando mucho intencionadamente, el gobierno lusitano ha proclamado oficialmente que se negaba a reconocer a un nuevo embajador, lo que lleva Chepy a declarar, con una manifiesta y calculada exageración, que la neutralidad portuguesa es hipócrita y que «la Corte de Portugal es quizá, entre todas las Cortes de Europa, la que más se opone a la Revolución francesa y más teme los progresos que puede conseguir».

\section{El «ciudadano» Darbault o la Revolución expulsada}

A principios de diciembre de 1792, el gobierno de París, probablemente para no provocar el fatal incidente diplomático que hubiera supuesto la designación de un nuevo embajador en Lisboa, nombra al «ciudadano Darbault» agregado a la legación en calidad de secretario $\left.{ }^{27}\right)$. De todas formas, la casi inexistencia de relaciones diplomáticas entre las dos naciones a partir de la destitución de Chalon se avenía muy bien con la inexistencia de un embajador en Lisboa. En realidad, y sin que el gobierno portugués pudiera llamarse a engaño, Darbault va a actuar como un auténtico embajador. Prueba de ello es que se le dan unas instrucciones (que antes no se dieron al sospechoso Chalon). Su misión, que también recubre la de un cónsul, consiste en lo siguiente: en indagar acerca de las relaciones entre las Cortes de Portugal y de Inglaterra; en socorrer

(27) Todos los datos proceden de CPP, vol. 121. 
a los residentes franceses perseguidos por las autoridades portuguesas; en informarse acerca de las razones del estancamiento del comercio franco-português; en conocer el destino de los barcos que salgan de Lisboa; y en vigilar las operaciones de armamento.

Después de pasar por Cataluña y Madrid, se presenta en la frontera hispano-portuguesa y es detenido algunos días cuando pasa por Elvas. Llega a Lisboa el 23 de marzo, donde recibe una acogida muy desagradable. Sin embargo, tiene con el ministro Luiz Pinto una entrevista útil cuyos resultados van a tranquilizar al gobierno de París: la Corte de Lisboa confirma su deseo de neutralidad, de que dará prueba al no expresar ninguna opinión sobre los sucesos de Francia; pero también seguirá fiel a su sistema de alianza que le obligará, en caso de necesidad, a proporcionar socorros a España y a Inglaterra, lo que ni siquiera se habría de interpretar como una manifestación voluntaria de hostilidad. Pero, oficialmente, Darbault se enfrenta con una situación harto embarazosa: no se reconoce la validez de su carta credencial y, varias veces, se recoge sus papeles.

Otra vez casi se llega a un punto de ruptura a mediados de abril cuando Darbault recibe la orden de salir de Portugal. Aparece a todas luces que el gobierno de París no está dispuesto a declarar la guerra, porque oficialmente no se interpreta la medida portuguesa como una medida de expulsión, de manera que la agresión cuya víctima no es nada menos que el sustituto del embajador no constituye finalmente un «casus belli». Incluso se llega a evitar otro incidente al conseguir la puesta en libertad de Darbault que, durante su viaje de regreso a Francia, había tenido la desgracia de caer en manos de los ingleses (Llegará a Saint-Malo a mediados de julio de $1793 \mathrm{y}$, a finales de diciembre, redactará un interesante informe sobre Portugal).

\section{La época de la guerra entre la Convención y España (1793-1795)}

Estos tres años de guerra señalan para las relaciones franco-portuguesas un periodo de extremada ambigüedad y confusión, como si de ambos lados los gobiernos se empeñaran en no declarar la guerra, aunque conocían a fondo las disposiciones hostiles del adversario, muy claras en el caso de Portugal que - como es sabido - mandó unas tropas a Cataluña que combatieron contra los soldados de la Convención. A pesar de lo borroso de la "política portuguesa» de la Convención y apoyándome sobre los escasos documentos que se refieren a ella en aquellos años, intentaré caracterizarla así: ya queda 
admitido que Portugal ha dejado de ser neutral respecto a Francia para venir a ser un enemigo. Lo atestiguan unas disposiciones militares (preparativos, decisiones y puesta en obra) francamente hostiles. Sin embargo, no existe una situación de beligerancia entre las dos naciones, ya que no hubo declaración de guerra. En definitiva, esa situación es satisfactoria porque Francia estima inútil o irrealizable abrir otro conflicto en la península, por las tres razones siguientes: Francia ya está en guerra con España; esta guerra con el país vecino impide que un ejército francés atraviese su territorio para invadir a Portugal por vía terrestre; por fin, faltan barcos para transportar soldados allí.

Esa extraña situación explica una serie de sucesos a primera vista contradictorios, que sólo se entienden cuando se recuerda que los dos gobiernos, aunque enemistados, no tienen la intención de que los incidentes pasen a mayores.

Ya vuelto a su patria Darbault, las noticias procedentes de Portugal escasean. Las pocas que llegan al gobierno de París tienen una virtud lenitiva: por ejemplo, se enteran las autoridades de que Edmond Church, cónsul de los Estados Unidos en Lisboa, socorre a los residentes franceses simpatizantes con la R.F., proporcionándoles dinero, vestidos y alojamiento $\left({ }^{28}\right)$. A finales de octubre de 1793 , un pequeño billete firmado por el ex-cónsul D'Hermand resume así, de manera muy alentadora, la situación en Lisboa:

«Estamos tranquilos aquí por el lado del gobierno que es prudente y avisado. La opinión general no es contraria a los franceses. Su comportamiento respecto a los navegantes portugueses ha causado un buen efecto" ${ }^{(29)}$.

Este análisis también lo hacía por su parte el negociante francés Ratton (cuyas «Cartas familiares», publicadas en el Bulletin des études portugaises de l'Institut Français au Portugal, fueron parcialmente utilizadas por Jacques Godechot en su rapidísimo artículo sobre «Le Portugal et la Révolution») $\left.{ }^{(30}\right)$. Yo destacaré los tres puntos siguientes a través de las observaciones de Ratton y de los pocos testimonios recogidos por mí en los archivos parisinos: primero - como lo asegura Ratton - , cuando empieza la guerra franco-española, «la opinión pública en Portugal no era en absoluto hostil a Francia

(28) CPP, vol. 121, AAE.

(29) CCL, 1792-1804, AAE.

(30) Ob. cit. 
ni a la Revolución. Ya a finales de noviembre de 1792 había escrito Cailhasson, probablemente con excesivo optimismo:

"Los portugueses, en general, se interesan fuertemente por el éxito de nuestra Revolución; están muy ávidos de noticias de Francia.... Manifiestan su satisfación cuando reciben noticias favorables a la causa de la libertad....» (31).

La segunda advertencia se refiere a la situación de los residentes franceses; mientras que los informes de Chepy y de Cailhasson habían dado a pensar que en 1791 y 1792 las autoridades se encarnizaban contra los «regicidas», a partir de 1793 - como lo escribe Ratton - «todos los franceses siguen disfrutando de paz, tranquilidad y protección» ${ }^{32}$ ). La tercera advertencia concierne al comercio franco-portugués: ha entrado en una total parálisis, lo que desespera a nuestro observador cuyos intereses estuvieron probablemente lesionados.

Cuando llegue la época de la conclusión de la paz entre España y Francia, el ministro Luiz Pinto de. Souza tendrá a bıen asegurar que la parálisis del comercio franco-portugués no fue tan absoluta como se pudo pensar en París, dado que «los barcos de comercio franceses pudieron seguir entrando en el puerto de Lisboa» $\left.{ }^{(33}\right)$. En cuanto a la represión policiaca, ni siquiera hubo detenciones - se atreve a sostener el ministro -, sino sólo algunas expulsiones de «individuos que ofendían las leyes y turbaban la tranquilidad pública».

Así que la sola manifestación realmente importante de beligerancia franco-portuguesa, amén de la actuación de la Legión Portuguesa en Cataluña, se limitó probablemente, al margen de las represalias acostumbradas (secuestro de bienes, detenciones, expulsiones...), a dos clases de agresiones por parte de los franceses: a unas tentativas de proselitismo revolucionario, y a la práctica del corso en mar que tuvo por consecuencia, según unos historiadores portugueses, la captura o la destrucción de cierta cantidad de barcos y de cargamentos de alto valor $\left(^{34}\right)$.

También señalo de paso un aspecto, más simbólico que sustancial, de la posible conceptualización de Portugal como nación en guerra (no declarada) con Francia: queda abierta

(31) CPP, vol. 121, AAE.

(32) J. Godechot, ob. cit.

(33) CPP, vol. 121, AAE.

(34) Véase, por ejemplo, Prince Romuald Giedroyc, Résumé de l'histoire du Portugal au XIX'e siècle (Librairie Amyot, Paris, 1875, p. 10): «Des croiseurs français brûlèrent et capturèrent pour plus de 200 millions de marchandises portugaises, venant des Indes et du Brésil». 
la posibilidad de que en las vehementes arengas pronunciadas en clubs revolucionarios, sociedades patrióticas o sociedades populares, Portugal haya estado asociado a España en el grupo de las naciones enemigas de la Convención. Para cerciorarse de ello habría que repasar la infinidad de proclamas, diarios y transcripciones de discursos parlamentarios en busca del eco popular que pudo tener, a escala local, la "política portuguesa» elaborada en las altas esferas parisinas. Sólo puedo proponer, en forma de botón de muestra, el extracto de la «adresse» (o sea llamada) de la Société Populaire del pueblecito de Alet a la Convención, el «15 ventose an II». Allí se ve cómo portugueses y españoles se hacen acreedores del mismo sentimiento de odio despreciativo y fanfarrón:

«Portugués, ponte a temblar ante la diosa de la libertad que hará enmudecer los oráculos fanáticos de tus dioses. Español, no te vanaglories de tu cobarde libertad....» (35).

Cuando se va acercando la época de la vuelta a la paz entre España y Francia, he aquí que Portugal que, de hecho, no había tenido ningún peso en la estrategia política francesa desde que empezó la guerra franco-española, vuelve a figurar en el juego diplomático francés. Se evidencia el fenómeno de la forma aritmética siguiente: en los volúmenes que recogen las actas del Comité de Salud Pública no hay ninguna alusión a Portugal en los 18 primeros tomos; hay una en el tomo XIX, con fecha del 28 de enero de 1795; otra en el XX y seis en el XXI, entre marzo y abril de 1795 . Por fin, se puede hablar de una «política portuguesa», porque las instrucciones que el Comité de Salud Pública envía al representante del Pueblo cerca del ejército de los Pirineos Orientales son realmente directrices diplomáticas, firmes y meditadas. He aquí el meollo del texto:

«Para conseguir mayor flexibilidad de aquel gobierno [de Madrid], hay que mostrarle que sus intereses consisten en hacer retroceder a Portugal a su antiquo estado, es decir hacer de él una provincia española. El gobierno francés estaría dispuesto a ayudarle en la conquista de este país $1 . \%$ porque, haciendo esto, la nación francesa no haría más que luchar contra una de las potencias ligadas contra ella y porque, luchando contra ella, tendría el derecho de destruirla 2.o/ porque, echando abajo al gobierno portugués, tendríamos la ventaja de auitar a Inglaterra una de sus provincias más ricas (pues Portugal no es más, en realidad, que una provincia inglesa)» ( ${ }^{36}$ ).

(35) Archives Parlamentaires, t. 88, p. 518.

(36) Actes du Comité du Salut Public, t. XX, p. 721. 
Cabe la posibilidad de que el destinatario de estas instrucciones, el representante del Pueblo Goupilleau (de Fontenay) haya propiciado esa «revitalización» del proyecto de invasión de Portugal; pero se da el caso curioso de que Goupilleau, tras haber aconsejado al Comité de Salud Pública una ofensiva contra Portugal, da marcha atrás repentinamente, explicando el 20 de marzo por qué se ha equivocado a propósito de esta guerra que anhelaba y reputaba fácil de ganar: 1. $\left.{ }^{\circ}\right)$ las dos Cortes de Lisboa y de Madrid están unidas por un casamiento; $2^{\circ}$ ) no podría alegar España ningún motivo verosímil para justificar un ataque contra Portugal, parte de cuyas tropas siguen luchando a su lado en España; $3 .^{\circ}$ ) el pueblo español está harto de guerra y la hacienda tan exhausta que todo aboga en favor de la paz. Quizá porque no le llegó a tiempo este convincente alegato, el Comité de Salud Pública, dirigiéndose unos días después a los representantes del Pueblo que están en Figueras, se mantiene fiel al proyecto inicial:

«Sin ninguna duda, si España desea en el tratado una cláusula mediante la cual la República la ayudará a conquistar a Portugal, hay que introducirla; vosotros fijaréis como os parezca más atinado la cantidad de tropas que habrá que proporcionar para dicho objeto, precisando que habrán de ser pagadas por España» ( $\left.{ }^{37}\right)$.

En realidad, la negociación no va a progresar en este sentido, probablemente porque Godoy, por las razones expuestas por Goupilleau, no tenía ningún interés en echarse sobre Portugal, no bien concluida la paz con la Convención. También se tomó en cuenta otro argumento táctico en el bando francés: lo mejor pareció concluir rápidamente una paz separada con España sin intervención de Portugal, para aislar a este reino, y concluir con él posteriormente una paz más ventajosa.

\section{De la Paz de Basilea (1795) al tratado abortado de 1797}

Efectivamente, como lo había previsto cínicamente el Comité de Salud Pública, la conclusión del tratado de paz franco-español $\left({ }^{38}\right)$ fragiliza la posición del gobierno portugués, y

(37) Idem, t. XXI, p. 335.

(38) Recuerdo de paso que el artículo 13 del tratado de Basilea (22 de julio de 1795) se refiere explícitamente a los soldados de la Legión Portuguesa que habían caído en manos de los franceses durante su actuación en el Rosellón o en Cataluña: «Los prisioneros portugueses que forman parte de las tropas de Portugal y que han servido en los ejércitos y marina de Su Majestad Católica serán igualmente comprendidos en el sobredicho canje. Se observará la recíproca con los franceses apresados por las tropas portuguesas de que se tratax. 
más todavia la firma del tratado de San Ildefonso que, en agosto de 1796, sella la alianza franco-española, incluyendo una cláusula que se puede calificar de anti-portuguesa. Así reza:

"S.M.C. se valdrá de su influjo o de su poder para empeñar $\mathrm{u}$ obligar a Portugal a que cierre sus puertos a los ingleses cuando esté declarada la guerra».

Así que, en el transcurso de los años 1795 y 1796, es lícito hablar de una "política portuguesa» más coherente, clara y estable que nunca. A esa mutación, en forma de homogeneización y fortalecimiento, contribuyó esencialmente, por supuesto, la sustitución, a la cabeza del país, de la Convención por el Directorio, instalado el 5 de brumario año IV (27 de octubre de 1795).

El despacho que el ministro Luiz Pinto de Sousa, secretario de Estado en el departamento de Asuntos Exteriores, manda, el 2 de julio de 1796, a su compatriota, el caballero de Carvalho, ministro plenipotenciario cerca del soberano de Madrid, revela indirectamente qué argumentos esgrime el Directorio contra la Corte portuguesa para poder acusarla de haber infringido, en los años anteriores, un pacto no escrito de neutralidad $\left({ }^{39}\right)$ :

1..$^{\circ}$ Portugal entró en la coalición anti-francesa.

$\left.2 .^{\circ}\right)$ Sus tropas luchan contra la República.

3. ) Los barcos franceses no podían entrar en sus puertos.

4. ) Los enemigos más implacables de Francia hallaban en Portugal una seguridad que prueba indiscutiblemente que defendían una causa común.

Se nota pues, del lado francés, una voluntad que es todo lo contrario de una voluntad de apaciguamiento y reconciliación. El endurecimiento de la posición francesa halla su expresión en el tratado franco-español de San Ildefonso. El comentario de Pérignon, embajador en Madrid, que se dirige al ministro de las Relaciones Exteriores, Delacroix, manifiesta que, más allá del cierre de los puertos a los barcos ingleses, el Directorio pretende, respecto a Portugal, «obligarle por la fuerza a separarse de Inglaterra, si no lo hace de buen grado». Pérignon, en una entrevista con Godoy, recalca ese punto, empleando los términos siguientes:

(39) CPP, Supplément vol. 9 (1796-1805), AAE - Salvo precisión contraria, todas las noticias que siguen están sacadas de este volumen. 


\section{La «Política Portuguesa» de la Revolución Francesa}

«El tratado que hemos firmado, Vd. y yo, nos lleva, por causa común, a la guerra contra Portugal, si esta potencia se niega a cerrar sus puertos a los ingleses y a romper absolutamente con ellos».

Confirmación de que existe ya, por lo mencs en el papel, cuando no en los actos, pero sí como doctrina, «una política portuguesa" del Directorio, los Directcres envían al general Pérignon, el 8 thermidor año IV (julio de 1796) una «Nota», mal nombrada, porque, en realidad, se trata de un interesante conjunto de puntos doctrinales, reiteraciones de postulados, definiciones de objetivos y consejos tácticos, que muestran la importancia creciente de Portugal a los ojos de las autoridades parisinas. Entre los postulados vienen los siguientes:

$10^{\circ}$ - Portugal necesita la paz con Francia, porque la alianza franco-española constituye una amenaza directa para él.

$20^{\circ}$ - Siendo a esas alturas Francia una potencia «triunfante y vigorosa», se puede imponer a Portugal unas condiciones duras.

$30^{\circ}$ - Si se abre la guerra con él, Francia saldrá victoriosa.

$4 .^{\circ}$ - La alianza con Portugal sería útil, pero no es indispensable.

La táctica me parece reducirse a los dos puntos siguientes:

$10^{\circ}$ - Hay que imponer la paz:

$20^{\circ}$ - Inmediatamente después, hay que imponer un tratado de alianza ofensiva y defensiva.

Como se puede notar, la ruptura no forma parte de los objetivos; a Francia no le interesa entrar en guerra con Portugal; pero sí se hablará de esa eventualidad como medio de presión, intimidación o chantaje.

La «política portuguesa» del Directorio no consiste, pues, en preparar abierta o secretamente una expedición militar a Portugal - aunque, como lo veremos, no faltan oficiales encumbrados para lisonjearse de ser llamados a dirigirla -, sino que consiste en formular, calibrar y justificar las exigencias que se expondrán en unas negociaciones que ya se anuncian ásperas, porque los Directores anhelan recuperar todos los territorios y todas las ventajas que los franceses abandonaron a los ingleses a lo largo de varios decenios. Sin entrar en todos los detalles - porque, esta vez, sí se puede hablar de un análisis pormenorizado de todas las relaciones franco-portuguesas pasadas y futuras -, me contentaré con enumerar esquemá- 
ticamente esas exigencias más o menos flexibles. Se trata, para Francia, de conseguir:

$10^{\circ}$ - el establecimiento de las relaciones comerciales en un plano de igualdad con las naciones más favorecidas;

$2 .^{\circ}$ - la libertad de introducir en Portugal los productos de las manufacturas francesas;

3. - - la admisión en los puertos portugueses de los barcos franceses de comercio y de corso;

4..$^{\circ}$ - la expulsión de todos los barcos ingleses;

$50^{\circ}$ - la cesión de la orilla septentrional del Amazonas, desde la desembocadura del río Negro hasta el Océano;

$60^{\circ}$ - la libertad de navegación en el Amazonas para Portugal, Francia y España;

7. - una indemnización de 25 millones de francos.

Esto forma la base de la negociación. Sobra advertir que el infeliz Portugal parece ser tratado como si saliera de una guerra encarnizada contra Francia. También sobra advertir que, en este momento, ha vuelto a surgir la imagen «literaturizada» que analizamos en la primera parte: la de un Portugal rico gracias a los minerales preciosos y a los diamantes que saca de sus posesiones americanas; la de un Portugal que, puesto a la cabeza de unas colonias americanas demasiado dilatadas para ser explotadas por él sólo, no perdería gran cosa en ceder parte de ellas a Francia que precisamente necesita plata y maderas tropicales; por fin, la de un Portugal que, avasallado por Inglaterra, ha de ser empujado hacia su «liberación».

El examen - para mí tedioso - del lentísimo y escabroso caminar de las negociaciones que duraron un año revela sin embargo que las autoridades francesas, en lugar de mantener una postura uniformemente rígida, en realidad modulan su firmeza según la importancia jerarquizada que atribuyen a los puntos que enumeré más arriba. La táctica me parece ser claramente la siguiente sobre cuatro puntos:

1. - - Intransigencia para la cesión de las tierras al norte del Amazonas.

$20^{\circ}$ - Intransigencia para conseguir reparaciones a favor de unos ciudadanos franceses maltratados durante la primera fase de la R.F.: encarcelamientos, secuestros de bienes, confiscación de bienes, como en el caso de Dupetithouars (En este dominio, el diplomático portugués se mostró muy conciliante).

3. - Transigencia para la indemnización (o, dicho de otra manera, se aceptará una cantidad menor). 
$4^{\circ}$ - Transigencia para la petición de exclusión de todos los barcos enemigos (en concreto, de no poder conseguir la exclusión de todos los barcos de las potencias en guerra con Francia, ésta se contentaría con la exclusión de los corsarios y de los barcos cogidos por ellos).

Si la progresión de las negociaciones fue - como dije antes - extraordinariamente sinuosa y sincopada, es que, por debajo de una fijación de objetivos nítidos, interfirieron un sinnúmero de protagonistas clandestinos, de influencias ocultas, de motivaciones inconfesables y de intereses egoístas. Todo esa mezcla constituye la realidad efectiva de la «política portuguesa» del Directorio que, como se echa de ver, es ya bastante distinta, no sólo de su definición programática, sino también de lo que puede captar el plenipotenciario portugués sentado a la mesa de las negociaciones.

Sólo así se podrá entender - y aún quedan cosas por descifrar - por qué, en el transcurso del año y medio aproximadamente que va de julio de 1796 a diciembre de 1797, la negociación presentó una serie de fases muy contrastadas, que yo especificaré así:

$1 .^{\circ}$ - Hasta brumario año $\mathrm{V}$ (octubre-noviembre de 1796): tensión, deterioro y ruptura $\left({ }^{40}\right)$, porque Francia mantiene todas sus exigencias.

$2 .^{\circ}$ - Hasta el 24 thermiror año V (10 de agosto de 1797): acercamiento mutuo, reconciliación y acuerdo.

$3 .^{\circ}$ - Hasta brumario año VI (octubre de 1797): anulación del acuerdo, primero por la Corte de Portugal y después por el Directorio.

Esa evolución errática ni se ha de achacar al negociador francés, el ministro Delacroix, ni al negociador português, Antonio Araujo de Azevedo, el cual, del lado portugués, fue tachado después, en gran parte injustamente, de débil o de traidor ${ }^{\left({ }^{41}\right)}$.

Mencionaré, para empezar - dada la importancia decisiva que yo atribuyo a este protagonista físicamente ausente de las negociaciones - el gobierno de Londres que, sobre todo después de la realización del acuerdo, presionó sobre el de Lisboa para que no firmara un tratado tan perjudicial para sus inte-

(40) CPP, vol 121, AAE.

(41) Véase al respecto varios documentos en Julio Firmino Judice Biker, Supplemento á colleç̧ão dos tratados, convençoes, contratos e actos publicos celebrados entre a coroa de Portugal e as mais potencias desde 1640...., tomo XI (Parte II), Lisboa, 1874. 
reses. No olvidemos que, en aquella época, los ingleses disporían en Portugal de 6000 soldados, dctados de artillería pesada, que podían acudir a las armas, desencadenar bombardeos u ocupar algunas plazas fuertes si al gobierno portugués le ocurriera desolidarizarse del aliado británico.

También maneja Godoy que, de puro pedir a Francia moderación, deja ya adivinar que no está dispuesto a lanzarse en una guerra contra Portugal, por la serie de razones que apunté anteriormente $\left({ }^{42}\right)$.

El juego diplomático francés se hace aún más enbrollado y móvil porque, en un momento dado, interviene un ligero cambio de orientación global de la política exterior del Directorio y porque - en este caso, de manera continua y difícilmente aprehensible y ponderable - se ejercen presiones exteriores y se inmiscuyen individuos a veces ajenos a la política.

El cambio producido por lo que se suele llamar «el pequeño golpe de estado del 18 fructidor» (que provoca la caída de los Directores Carnot y Barthélémy) se traduce, en el dominio diplomático, por un reforzamiento de las ambiciones y presiones francesas. La carta que el principal beneficiario de esa revolución interna, Talleyrand, manda al general Bonaparte, cuya autoridad va también en aumento, confirma la nueva orientación:

«Ciudadano general, los sucesos del 18 fructidor han de repercutir necesariamente fuera. Atestiguarán en Europa la fuerza del gobierno y el vigor de la República que acaba de desbaratar a los enemigos interiores, con esa facilidad de la que Vd ha dado un tan hermoso ejemplo a los enemigos extranjeros. Han de renunciar a las esperanzas que las potenciais europeas habian fundado en nuestras disensiones interiores, aniquilan el apoyo que se habían dado, finalmente derriban muchos obstáculos que se oponían a la paz. El tono de las negociaciones, pues, ha de subir aún más» (43).

Por consiguiente, y aunque la oposición del gobierno inglés a la ratificación del acuerdo al que habían llegado Delacroix y Araujo de Azevedo pueda explicar por sí sólo el fracaso final del convenio, también creo que hay que tomar en cuenta - lo que nunca han hecho los historiadores - la «vigorización» de la diplomacia francesa del otoño de 1797 para en-

(42) Véase A. Fugier, ob. cit.

(43) Carta transcrita por Michel Poniatowski, Talleyrand et le Directoire, 1796-1800 (Librairie Académique Perrin, Paris, 1982, p. 274). 
tender aún más fácilmente que la nueva rigidez de la posición de los Directores pone al gobierno portugués en el mayor aprieto, acabando de convencerle de que un nuevo aflojar en la resistencia suscitará la cólera de Londres.

Pero lo que no queda claro es el papel efectivo desempeñado por el nuevo ministro de Relaciones Exteriores, Talleyrand. Ni siquiera su último biógrafo, Michel Poniatowski, llegó a calibrar el tamaño de los «pots-de-vin» o - como rezan los documentos portugueses de la época - de las «dádivas secretas» $\left.{ }^{44}\right)$ que recibió, en compañía del Director Barras, para que se mostrara complaciente con Portugal. Según la lógica - pero con Talleyrand no cabe hablar de lógica y rectitud cuando tercian intereses financieros egoístas -, este personaje hubo de defender, respecto a Portugal, una posición conciliadora. Es verdad que fue Talleyrand - amigo de Araujo - quien concedió al gobierno de Lisboa, a mediados de octubre, un nuevo plazo de un mes para la ratificación del tratado. Pero también es el quien, diez días después, participa a Araujo que el gobierno de París no se avendrá a aceptar ya la menor modificación favorable a Portugal.

Cualquiera que sea la actitud sinuosa de Talleyrand, queda claro que, tras la fachada de una "política portuguesa» coherente y ya estabilizada, perduran las disensiones en el mismo seno del Directorio en cuanto a la política extranjera, entendida globalmente, y que, por consiguiente determina la «política portuguesa». Incluso tras el 18 fructidor, Talleyrand instalado en su nueva función ministerial no podría imponer una política blanda con Portugal si una tendencia dura o endurecida predominara entre los Directores. Precisamente, después del 18 fructidor, la eliminación de Barthélemy debilita el bando de la moderación y refuerza correlativamente el bando de la intransigencia que cuenta sobre todo con Rewbell y La Révellière. De Carnot no llego a hacerme una opinión segura porque, si bien es verdad que el antiguo "Padre la victoria» del año II, enérgico e inspirado, ha bajado mucho de tono, también es verdad que el negociador Araujo lo contempla como el enemigo $n .^{\circ} 1$ de su país, porque lo cree dispuesto a mandar una expedición militar (Así lo escribe al ministro Luiz de Pinto, el 26 de octubre de 1797). Tampoco me atreveré a decir que el gobierno portugués y su negociador ganaron algo en la sustitución de Delacroix por Talleyrand como ministro de las Relaciones Exteriores.

(44) Cf. Biker, ob. cit., p. 530, Idem para las referencias que siguen, salvo excepción. 


\section{Revista de História das Ideias}

La «política portuguesa» del Directorio también la quieren impulsar, y veces anhelan dirigirla o encarnarla algunos militares que no tienen la suerte de poder ilustrarse como entonces lo está haciendo Bonaparte en Italia. Por ejemplo, Araujo cree saber, y lo escribe a Luiz Pinto el 22 de noviembre, que

"el general Massena tiene un partido en el Directorio para ser comandante en jefe contra nosotros, aunque se ha prometido el mismo mando al general Scherer, pariente del Director Rewbell....».

También puedo citar, utilizando fuentes distintas, otro general "va-t-en guerre», es decir partidario de abrir un frente militar que le permitiera medrar o adquirir fama: se trata del general Pérignon, ex-embajador en Madrid, conocido en París por querer encabezar el ejército de invasión franco-español; el 21 pluvioso, había escrito a Delacroix:

«Si Portugal no decide romper en el acto con los ingleses, tenemos que conquistar ese Reino y agregarlo a los estados de S.M.C.» (45).

Por fin, fuera del área político-militar, se mueven silenciosamente (para nosotros) unos individuos o grupos de individuos que, según el caso, encontrarían ventajas o inconvenientes en una guerra que se hiciera a Portugal. Ellos también influyen en la «política portuguesa» del Directorio. Como no les toca redactar informes, no parecerá paradójico que las huellas de esas solicitudes se rastreen en los archivos portugueses, porque no escapan a la mirada aguda de Araujo. Este se ha enterado, por ejemplo, de que «las casas Girardot, de Chaumont, de Laage y socios» tienen interés particular en que el tratado se ratifique, porque la importante indemnización que cobraría Francia dejaría algunas huellas doradas al transitar por esos bancos respectivos. Pero, en sentido opuesto, los tradicionales abastecedores del ejército francés prefieren la ruptura del convenio, porque los seduce más la perspectiva lucrativa de un conflicto armado. Por fin, los negociantes y navieros de Burdeos manifiestan su oposición a la firma de un tratado, incluso acompañada por una fuerte indemnización que recaería parcialmente en ellos, porque - como lo explican con una total frialdad - la práctica del corso les proporciona beneficios más cuantiosos que ese hipotético cobro de una fracción de la indemnización. Dicho de otro modo, la continuación de

(45) CPP, Supplément 9, AAE. 


\section{La «Política Portuguesa» de la Revolución Francesa}

una situación mal determinada de beligerencia larvada les conviene perfectamente a esos burgueses del Gironde.

Cuando ya se dan cuenta Talleyrand y los Directores de que el gobierno de Lisboa, sometido a la presión amenazante y colérica de Londres, sólo procura tergiversar, regatear, ganar tiempo, inventar disculpas para explicar una tardanza en realidad voluntaria, el Directorio que, por su lado, había conseguido la aprobación de los dos Consejos (de los Quinientos y de los Antiguos) toma la decisión del rompimiento: en octubre de 1797 a su vez declara la nulidad del tratado de paz que - como lo proclama desdeñosamente - había tenido la magnanimidad de conceder a la reina de Portugal $\left({ }^{46}\right)$.

\section{Conclusión}

Al final del año 1797, la evolución de las relaciones diplomáticas franco-portuguesas ha llegado a un punto de claridad meridiana nunca alcanzado hasta entonces. Desgraciadamente, la claridad consiste en poder decir que las hostilidades se han reanudado entre las dos naciones (aunque el gobierno de Portugal evita emplear expresiones tan rotundas y peligrosas como las que emplean los Directores).

Ese corte cronológico, a pesar de su relativa arbitrariedad, permite inspirar, por lo menos, la rápida conclusión siguiente: desde el principio de la Revolución y hasta el establecimiento del Directorio en diciembre de 1795 , me atreveré a decir que no hubo una "política portuguesa» efectiva, por una razón obvia: porque ni siquiera se había elaborado en París. Sin embargo, los políticos de París disponían de la mayor parte de los informes, con análisis de la situación política, datos económicos y militares, proyectos de intervención armada o de expediciones en el ultramar, que constituían el indispensable soporte de una "política portuguesa» coherente y atinada. En definitiva, el Directorio trabaja con el mismo material documental, ligeramente aumentado y actualizado, para concebir - y la concibió y explayó - una «política portuguesa» enérgica y innovadora cuyo coronamiento debía de ser, no la habitual (en aquel entonces) "guerra de liberación», sino un tratado de paz, inmediatamente seguido de un tratado político-comercial desequilibrado, es decir gravoso para Portugal, pingüe para Francia, y - no olvidemos lo esencial, tal vez - perjudicial para Inglaterra.

(46) CPP, vol. 121, AAE. 
Con la debida matización exigida por la enorme amplitud del periodo abarcado (del Directorio al Primer Imperio), creo que sigue válida grosso modo la definición de la «política portuguesa» de los gobiernos franceses, tal como la proponía, en 1911, R. Guyot en su libro sobre Le Directoire et la Paix de l'Europe:

«El plan de acción.... era: llevar a España a una demostración, y si hiciera falta a una guerra contra Portugal; se echaría a los ingleses de Lisboa, los portugueses pagarían una enorme cantidad de dinero, firmarían con Francia un tratado de alianza de comercio, cediéndole las tierras entre Guyana y el Amazonas, que luego daría a España para recuperar en cambio la Luisiana» ${ }^{(47)}$.

(47) Citado por J. Gagé, ob. cit., p. 69 : 